\title{
Response of Oyster Shell Ash Blended Cement Concrete in Sulphuric Acid Environment
}

\author{
Imoh C. Attah ${ }^{1 *} \quad$ Roland K. Etim ${ }^{1} \quad$ John E. Sani ${ }^{2}$ \\ 1.Department of Civil Engineering, Akwa Ibom State University, Ikot Akpaden, Nigeria \\ 2.Department of Civil Engineering, Nigeria Defence Academy, Kaduna, Nigeria
}

\begin{abstract}
An experimental investigation was carried out to study the potentials of oyster shell ash (OSA) to be used as supplementary cementitious material (SCM) exposed to sulphuric acid environment. Experiments were carried out by supplementing $5-20 \%$ of OSA by weight of cement in concrete. The mix ratio used was 1:2:4 (binder, sand and granite) with water cement ratio maintained at 0.5 . A total of 320 cube specimens $(150 \mathrm{~mm} \mathrm{x} 150 \mathrm{~mm} \mathrm{x}$ $150 \mathrm{~mm}$ ) were cast and tested for compressive strength at 7, 14, 21 and 28 days of curing in potable tap water and $(5,7.5$ and $10 \%)$ sulphuric acid solutions. It has been deduced that the compressive strength of concrete specimen progressively increased with longer curing periods and decreased with OSA content for specimen immersed in water whereas for specimen immersed in sulphuric acid solutions the compressive strength decreased with longer curing period, OSA content as well as sulphuric acid content. Generally, results of the statistical analysis showed that sulphuric acid concentrations, OSA contents and curing periods have significant effect on the compressive strength of concrete. The use of OSA as SCM did not mitigate the adverse effects of sulphuric acid on the compressive strength of cement blended with OSA.
\end{abstract}

Keywords: Compressive strength, Oyster shell ash, Statistical analysis, Sulphuric acid environment, supplementary cementitious material

DOI: $10.7176 / \mathrm{CER} / 11-4-07$

Publication date:May $31^{\text {st }} 2019$

\section{Introduction}

Concrete is a durable material with little or no maintenance except when it is exposed to aggressive surroundings (Shetty, 2009). Sulphate attack is one of the most destructive surroundings that influence the mechanical and physical properties of concrete structures. The reaction of sulphate ions with calcium hydroxide and calcium aluminate hydrate to form ettringite and gypsum had been reported by (Nabil, 2016; Salah, 2007). They concluded that these products (ettringite and gypsum) lead to cracking, deterioration, expansion and deformation of hardened concrete structures. Consequently, the internal deterioration of concrete structures could be due to sulphate content in the cement while the external deterioration could be as a result of concrete exposure to sulphate environment. Several researchers are in agreement to the fact that acids have a profound effect on the strength and other properties of concrete (Zivica and Bajza, 2001: Turkel et al. 2007).

Mineral admixtures have been used to partially replace cement in concrete (Sai-Prasad and Jha, 2006; Mehta and Monteiro, 2006). The declining effect brought by chemical attack on concrete, the development of acid resistant cementitious material using multiple mineral admixtures had been performed by Ookame, et al., (2013). Commonly used mineral admixtures are fly ash, silica fume and rice husk ash (Reddy et al. 2012; Bhikshma et al. 2009; Zhang and Mohan 1996; Etim et al. 2018). Soeda et al. (1991) confirmed that the multiple uses of mineral admixtures can significantly reduce the erosion due to sulphuric acid attacks. The use of pozzolanas in concrete have been reported to mitigate the effect of sulphates and alkali - silica reaction, especially deleterious in concrete structures, by the development of a faster pozzolanic reaction (Sahmaran et al. 2007).

Large quantities of oyster shells are found in the coastal area of Niger delta region of Nigeria. Most of which are waste with no further use after the edible part is stripped off, except that a small amount is used in lieu of aggregates for temporary and remedial measures to cover up muddy areas for easy road access. Therefore, piles of oyster shell are common in regions of oyster production with no additional exploitation and thus constitute nuisance to the environment. The chemical and microstructure analyses of oyster shell revealed that oyster shells are predominantly composed of calcium oxide $(\mathrm{CaO})$ (Yoon et al. 2003), similar to that of lime, which has been used for soil stabilization (Spangler and Handy, 1982). In addition, Zhong et al. (2012) reported that oyster shells can be utilized for producing medium and high quality cement. Construction material mixed with crushed oyster shell and sand was used for sand compaction piles to improve soft soils underneath a breakwater port (Miyaji and Okamura, 2000). Oyedepo (2017) made used of crushed oyster shell as a replacement for fine aggregate in bituminous mix design. No concrete strength increase was found by adding sintered and pulverized oyster shells in concrete (Wu, 2000). Zhong et al. (2012) reported that the compressive and rupture strengths of mortar containing $10 \%$ oyster shell powder replacement with cement was close to the control ( $0 \%$ oyster shell powder). This signifies that a threshold of $10 \%$ oyster shell powder increased the 
compressive strength of mortar. Similarly, Abinaya and Venkatesh (2016) reported that concrete containing oyster shell power to an extent of $5 \%$ shows better strength and durability characteristics when compared to the concrete with $0 \%$ of oyster shell power. Olivia et al. (2015) concluded that concrete containing ground seashell yielded relatively better tension properties, but lower compressive strength and modulus of elasticity than the control concrete. Furthermore, the feasibility of using sea shells ash as admixtures for concrete according to (Etuk et al. 2012) showed that the optimum compressive strength was obtained with $15 \%$ replacement level of oyster shell ash (OSA).

From the foregoing, the pozzolanic nature of OSA provides a basis for it use as an admixture in cement. In addition, pozzolans in concrete had been reported to mitigate the effect of sulphate and alkali-silica reaction which is deleterious in concrete structures (Sahmaran et al. 2007). Therefore, the use of OSA as admixture in cement concrete cured in acid media if found useful would provide a new frontiers of knowledge. The principal objective of this study is to evaluate the compressive strength of OSA-cement concrete placed in water (control media) and 5, 7.5 and $10 \% \mathrm{H}_{2} \mathrm{SO}_{4}$ acid concentration. It is believed that the understanding of the compressive strength performance based on its resistance to sulphuric acid can lead to the advancement of much higher quality acid resistant cementitious material.

\section{Materials}

The materials used in this study were oyster shell ash (OSA), Portland limestone cement (grade 32.5), fine aggregate (sand), coarse aggregate (gravel), sulphuric acid $\left(\mathrm{H}_{2} \mathrm{SO}_{4}\right)$ and water. The cement which was purchased in an open market matches with the requirements of CEM II class cements as defined in NIS 444-1 (2003). The fine aggregate (sand) was obtained from a river bed in Mkpat Enin, Akwa Ibom State, Nigeria and was prepared to BS EN 12620 (2002) requirements. Coarse aggregate is crushed granite of maximum size $20 \mathrm{~mm}$ and conforms to BS EN 12620 (2002). All aggregates were free of deleterious materials. The water used throughout the duration of the research was a potable tap water obtained within Akwa Ibom State University campus. It satisfies ASTM C1602-12 (2012) requirement of water for use in concrete mixtures. The sulphuric acid was procured from an open market and different concentrations of its solution were prepared in the laboratory.

\subsection{Production of Oyster Shell Ash}

The oyster shells were obtained from a dump site in Uyo Local Government Area, Akwa Ibom state, Nigeria. The shell was collected with the aid of a shovel from the heap into a sack bag and was transported to the concrete laboratory of the Department of Civil Engineering, Akwa Ibom State University. The collected oyster shells were thoroughly washed to remove dirt and subsequently oven dried at a temperature of $105 \pm 5^{\circ} \mathrm{C}$ for twenty four hours. The oven dried oyster shells were later transferred to an electric furnace with elevated temperature set at $900^{\circ} \mathrm{C}$ and allowed to calcine for a period of four hours. The ash was allowed to cool before grinding using a grinding machine to obtain a finer particle. The resulting finer particle was sieved through BS sieve $(75 \mu \mathrm{m})$ and kept in an air - tight polythene bags for preservation until it was ready for usage.

\section{Methods}

\subsubsection{Mix proportions}

In total, five mixes of concrete were cast. The first mix was a control mix with $100 \%$ PLC. The remaining mixes contained PLC with varying percentages of OSA. The water-cement ratio was kept constant at 0.5 for all the blends. Details of mix proportion are shown in Table 1.

Table 1. Mix proportions of OSA blended cement concrete

\begin{tabular}{|c|c|c|c|c|c|}
\hline Materials & Control & $5 \%$ OSA & $10 \%$ OSA & 15 OSA & $20 \%$ OSA \\
\hline PLC $(\mathrm{kg})$ & 15 & 14.25 & 13.5 & 12.75 & 12 \\
\hline OSA $(\mathrm{kg})$ & 0 & 0.75 & 1.5 & 2.25 & 3 \\
\hline Fine aggregates $(\mathrm{kg})$ & 30 & 30 & 30 & 30 & 30 \\
\hline Coarse aggregates $(\mathrm{kg})$ & 60 & 60 & 60 & 60 & 60 \\
\hline Water $(\mathrm{kg})$ & 7.5 & 7.5 & 7.5 & 7.5 & 7.5 \\
\hline
\end{tabular}

3.1.2 Specimen preparation

Mixing of the concrete was done manually, a mix ratio of 1:2:4 was adopted with the percentage of replacement varying for each mix. The percentage replacement of cement with OSA ranged from the control mix of 0 to $20 \%$ in steps of $5 \%$ and batching was done by weight. A constant water cement ratio of 0.5 was selected in all mixes. After homogeneous mixing of fresh concrete, it was cast into standard steel mould of dimensions $150 \mathrm{~mm} x$ $150 \mathrm{~mm} \times 150 \mathrm{~mm}$ moulds as outlined in BS 8110 (1997). The fresh concrete was placed in three layers with each layer compacted manually by a tamping rod. All freshly cast specimens were left in the moulds for 24 hours before demoulding and curing in their different media until the time of testing. For the first set of specimens, eighty (80) cubes were cast and cured in potable water for 7, 14, 21, 28 days. Also, the second set of specimens numbered two hundred and forty (240) cubes were cast and cured in sulphuric acid $\left(\mathrm{H}_{2} \mathrm{SO}_{4}\right)$ environment with 
concentrations of $(5,7.5$ and $10 \%$ concentration in water) for 7, 14, 21, 28 days. Four separate curing media considered in this study were control (100\% potable water), 5, 7.5, $10 \%$ concentration of sulphuric acid. Cubes were placed in compressive testing machine and load applied gradually until the specimen fails. A total of three hundred and twenty (320) cubes were made and crushed.

\subsection{Workability}

The degree of workability of the fresh concrete mix was determined by the slump test. The slump test was carried out in accordance with the requirement of BS EN 12350 (2009). Fresh concrete was placed into a slump cone in three layers and compacted with a tamping rod to ensure the removal of all air pockets. The slump cone was removed and the slump height was determined by measuring the difference between the cone height and the fresh mix. This test was performed for each mix percentage variation of OSA.

\subsection{Density}

The density test was carried out in accordance with BS 1881, Part 114 (1983). At the completion of each curing period, the concrete cubes were weighed with the aid of an electric weighing machine balance. Density is calculated as mass of concrete cube $(\mathrm{kg})$ divided by volume of concrete cube $\left(\mathrm{m}^{3}\right)$ and expressed in $\mathrm{kg} / \mathrm{m}^{3}$.

\subsection{Compressive strength}

The compressive strength test was carried out in accordance with BS EN 12390, Part 3 (2009) specifications. For each percentage of replacement and curing age, four cubes were made and crushed to obtain the average strength in accordance with the specifications in BS1881 Part 116 (1983). The concrete specimens were cured in water and sulphuric acid $\left(\mathrm{H}_{2} \mathrm{SO}_{4}\right)$ environment with concentrations of $(5,7.5$ and $10 \%$ concentration) for $7,14,21,28$ days. The influence of the concentration of the curing media on the compressive strength of OSA-PLC blended concrete was evaluated by measuring the reduction in compressive strength using the expression in equation (1);

$$
\operatorname{RCS}(\%)=\frac{C_{w}-C_{S}}{C_{w}} \times 100
$$

where RCS is reduction in compressive strength (\%), $\mathrm{C}_{\mathrm{w}}$ is the average compressive strength $\left(\mathrm{N} / \mathrm{mm}^{2}\right)$ of three specimens cured in water and $\mathrm{C}_{\mathrm{s}}$ is the average compressive strength of three specimens exposed to sulphuric acidic environment.

\section{Results and Discussion}

\subsection{Materials Characterization}

The particle size distribution for fine and coarse aggregates is shown in Figure 1 and 2, respectively. The fine and coarse aggregates were sieved with the largest particles at $4.75 \mathrm{~mm}$ and $20 \mathrm{~mm}$ respectively in the BSI sieve. In practice, coarse aggregate of maximum size $20 \mathrm{~mm}$ is commonly used for reinforced concrete (Shetty, 2012). The coefficient of curvature $(\mathrm{Cc})$ for coarse aggregate is 1.05 . The particle size distribution of the sand shown in Fig. 1, indicate that the sand used falls within the zone 2 according to the grading limits for fine aggregates BS 882 (1992), which implies that it is suitable for construction purposes. Also, the sand satisfies the requirement of lower and upper limits of the percentage by mass passing as specified by BS 882 (1992). It could be observed from the grading curves that the Coefficient of uniformity $(\mathrm{Cu})$ and Coefficient of curvature $(\mathrm{Cc})$ for the fine aggregates are 1.87 and 1.14 respectively. Thus, the sand can be said to be classified as uniformly graded since the value of $\mathrm{Cu}$ is less than 2 as stipulated in ASTM D $422-63$ (1998). The chemical composition of OSA reveal that it is a low reactive pozzolana due to a combined $\mathrm{Al}_{2} \mathrm{O}_{3}, \mathrm{Fe}_{2} \mathrm{O}_{3}$ and $\mathrm{SiO}_{2}$ content of $26.98 \%$, which is lower than the minimum value of $70 \%$ as stipulated in ASTM C 618 (2008) for a good pozzolana. The CaO content $(56.99 \%)$ in OSA also makes it to possess some self-cementing properties. The specific gravity of OSA was found to be 2.33 , cement was 3.14 , and sand (fine aggregate) was 2.45 while that of coarse aggregate was 2.65. The chemical composition of Portland limestone cement and oyster shell ash used is presented in Table 2. 


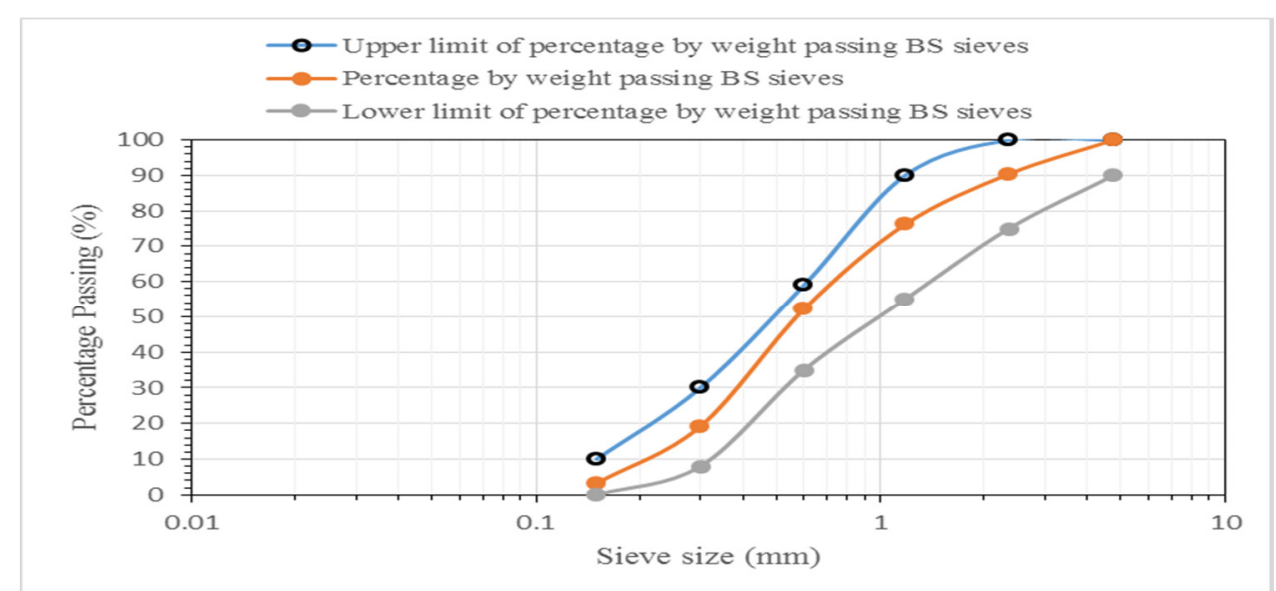

Figure 1. Particle size distribution for fine aggregate

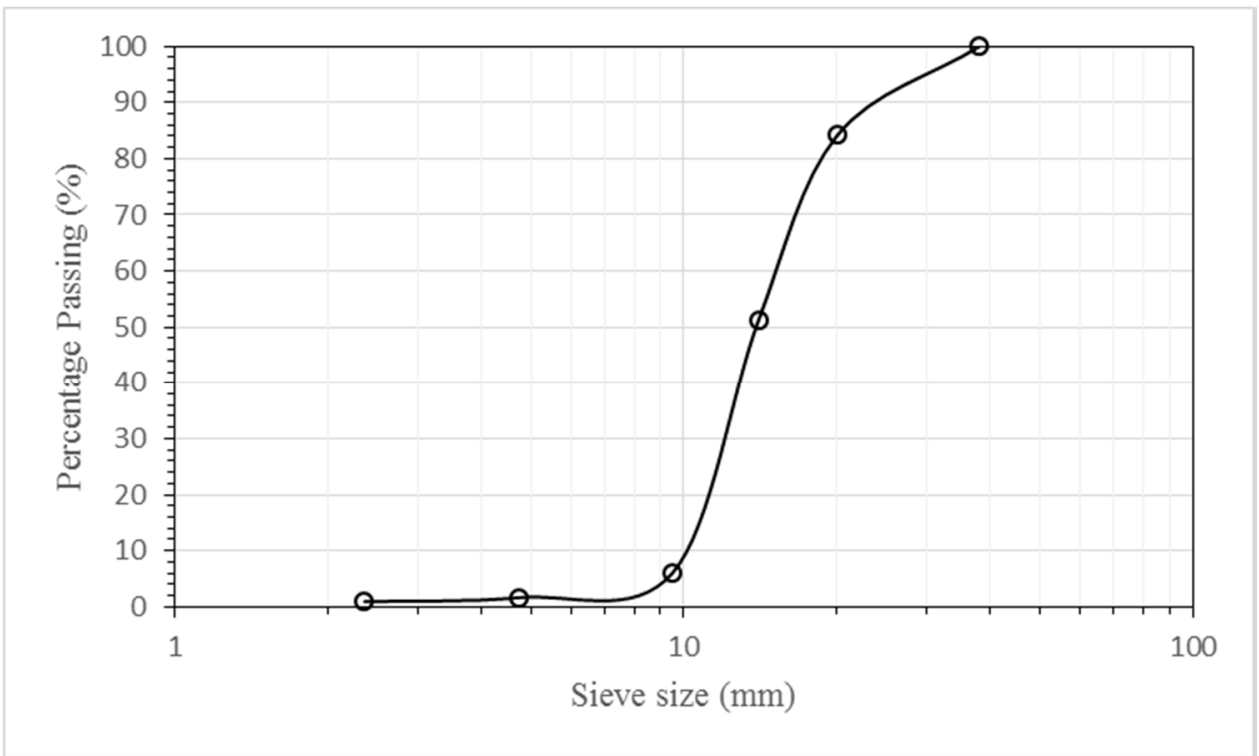

Figure 2. Particle size distribution for coarse aggregate

Table 2. Oxides composition of Portland limestone cement and oyster shell ash used

\begin{tabular}{|c|c|c|}
\hline Oxides & Portland limestone cement & Oyster shell ash \\
\hline $\mathrm{Fe}_{2} \mathrm{O}_{3}$ & 2.70 & 4.3 \\
\hline $\mathrm{Al}_{2} \mathrm{O}_{3}$ & 5.05 & 5.97 \\
\hline $\mathrm{SiO}_{2}$ & 21.00 & 16.71 \\
\hline $\mathrm{CaO}$ & 63.10 & 56.99 \\
\hline $\mathrm{MgO}$ & 1.40 & 0.2 \\
\hline $\mathrm{SO}_{3}$ & 2.53 & 0.12 \\
\hline $\mathrm{K}_{2} \mathrm{O}$ & 0.50 & - \\
\hline $\mathrm{TiO}_{2}$ & - & 0.041 \\
\hline $\mathrm{Na}_{2} \mathrm{O}$ & 0.45 & 0.35 \\
\hline $\mathrm{LOI}$ & 1.01 & - \\
\hline
\end{tabular}

4.2 Workability test on fresh concrete

The workability of fresh concrete, as determined by the slump test with varying percentages of cement replaced with OSA is presented in Table 3. The results show that slump decreases with increased OSA content in concrete. These results are consistent with the findings of (Olusola and Umoh, 2012: Etim et al. 2017: Attah et al. 2018). 
Table 3. Slump test result of OSA-PLC blended concrete

\begin{tabular}{|c|c|}
\hline Percentage replacement (\%) & Slump (mm) \\
\hline 0 & 59 \\
\hline 5 & 41 \\
\hline 10 & 33 \\
\hline 15 & 29 \\
\hline 20 & 27 \\
\hline
\end{tabular}

\subsection{Density of Specimen}

The variation of density of concrete cubes cured for 7, 14, 21 and 28 days with OSA replacement is shown in Table 4. The density of cubes ranged from $2355 \mathrm{~kg} / \mathrm{m}^{3}$ to $2588 \mathrm{~kg} / \mathrm{m}^{3}$, according to (Neville, 2000) these values lies within the range of 2200 to $2600 \mathrm{Kg} / \mathrm{m}^{3}$ specified as density values for normal weight concrete. For the specimens without OSA, it has been revealed that the density of cubes increased with curing age, which portrays that there is no deterioration of the concrete. This is consistent with the findings of Neville and Brooks (1997). The OSA-PLC blended concrete had their densities lower than that of $100 \%$ cement at all replacement levels. The decrease could be as a result of lower specific gravity of OSA compared to cement (Bapat 2012; Sathawane et al. 2013). It was also observed that the densities decrease with curing age which is consistent with literature that supplementary cementitious materials (SCMs) enhances reduction in densities of concrete with time due to the consumption of $\mathrm{SiO}_{2}$ that is present in SCMs (Bapat, 2012; Sathawane et al. 2013; Page and Page 2007).

Table 4. Density of OSA-PLC blended concrete Cubes at Different Curing Ages $\left(\mathrm{Kg} / \mathrm{m}^{3}\right)$

\begin{tabular}{|c|c|c|c|c|c|}
\hline Curing age ( Days) & $0 \%$ OSA & $5 \%$ OSA & $10 \%$ OSA & $15 \%$ OSA & $20 \%$ OSA \\
\hline 7 & 2553 & 2420 & 2411 & 2394 & 2385 \\
\hline 14 & 2562 & 2411 & 2397 & 2391 & 2389 \\
\hline 21 & 2578 & 2405 & 2388 & 2375 & 2367 \\
\hline 28 & 2588 & 2401 & 2374 & 2369 & 2355 \\
\hline
\end{tabular}

4.4 Compressive strength of specimens cured in potable water $\left(0 \% \mathrm{H}_{2} \mathrm{SO}_{4}\right)$

The relation between the compressive strength of concrete produced with cement replaced with varying percentages of OSA content cured in potable water at different curing ages is shown in Fig. 3. Compressive strength test was carried out for each of the four mixes at four different ages: 7, 14, 21 and 28 days. At the ages of 7,14, 21 and 28 days curing, the trend was that of an increase in compressive strength with curing age and decrease with OSA content for all the blends. This result is consistent with the behaviour of supplementary cementitious materials (SCMs) (Shetty, 2005; Adesanya and Raheem 2009). It can be seen that the strength development for the control mix (100\% PLC) was much faster than the other mixes containing cement replaced with OSA as shown in Fig. 3. At 7 day curing age, the compressive strength of the control mix was $20.98 \mathrm{~N} / \mathrm{mm}^{2}$ while others varied between 15.96 and $20 \mathrm{~N} / \mathrm{mm}^{2}$. Regardless of the fact that compressive strength increase with curing age for the respective OSA replacement. The strength gain by the mix containing OSA is comparatively lower than the control mix. This could be as a result of a slower rate of hydration of OSA compared to cement, similar to the findings of (Attah et al. 2018) who worked with periwinkle shell ash (PSA). Another reason could be that, the lime contained in the OSA does not provide improvement of concrete strength as the pozzolanic products of concrete already contain lime, and therefore no positive effect is detected for concrete strength. This is consistent with the report of (Liang and Wang 2013).

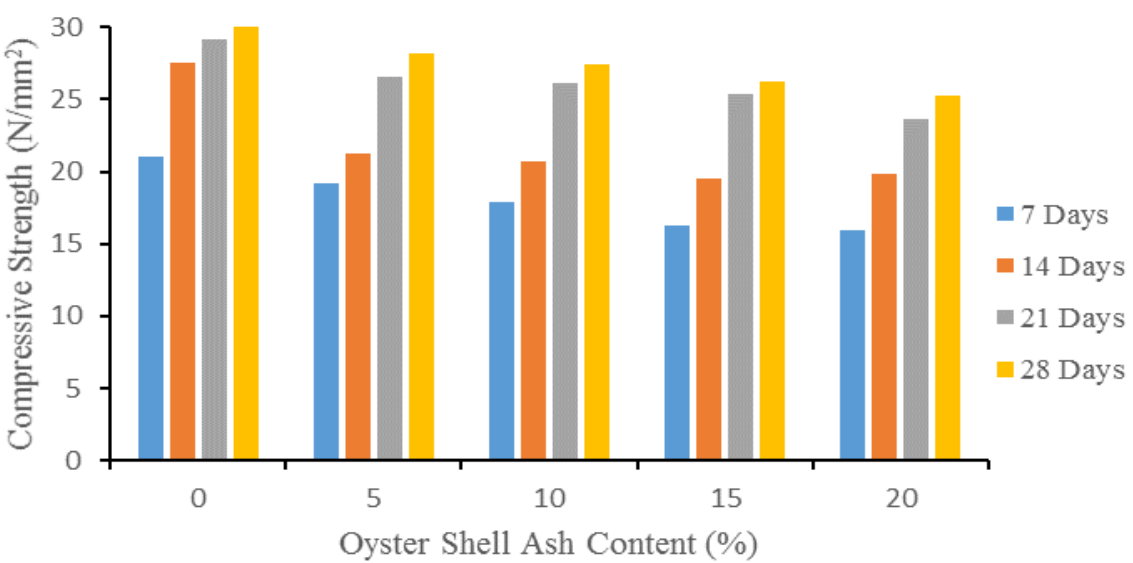

Figure 3. The Variation of compressive strength of blended cement -OSA concrete cubes with OSA replacement cured in potable water. 


\subsection{Compressive strength of specimens cured in sulphuric acid solutions}

The variation of compressive strength of concrete produced with cement replaced with varying percentages of OSA content cured in different concentration of sulphuric acid solutions $(5,7.5$ and $10 \%)$ and cured at different ages are shown in Figs. 4, 5 and 6. Notwithstanding the concentration of curing media, the results revealed a general decrease in compressive strength of cubes with increasing OSA content for the various curing ages of 7 , 14, 21 and 28 days. This decrease could be unconnected with the slow hydration rate of OSA as earlier mentioned. However, by way of comparing these results, it can be observed that the compressive strength decreased with increased concentration of the curing media. The immersion in acid solution probably gave rise to a reaction of the acid with the alkaline hydration products of cement/concrete matrix to form $\mathrm{CaSO}_{4 \cdot 2} \mathrm{H}_{2} \mathrm{O}$ (gypsum) and $3 \mathrm{CaO} \cdot \mathrm{Al}_{2} \mathrm{O}_{3} \cdot 3 \mathrm{CaSO}_{4} \cdot 31 \mathrm{H}_{2} \mathrm{O}$ (ettringite) (Yuan et al. 2013). The formation of these products had been reported to be responsible for the decrease in compressive strength with increase in acid concentration (Yuan et al. 2013; Zivica et al, 2012; Olonade et al. 2014; Neville 2008). Also, as concrete ages, the deteriorating effect of the acid increases, this agrees with (Turkel et al., 2007). The strength reduction was much with increase in acidic concentration particularly at 28 days. Sulphuric acid attack was more severe on the concrete cubes containing $20 \%$ OSA partially replaced with cement than other replacement levels. This implies that OSA could not mitigate the effect sulphuric acid. The degree of deterioration reaction is in line with Le Chaterlier's principle and the result is consistent with the results of experimental work by (Reddy et al. 2012).

The variation in reduction of compressive strength with OSA content, curing age and acid medium is shown in Table 5. The percentage reduction in compressive strength (RCS) of specimens immersed in sulphuric acid solution increases with increase in sulphuric acid concentration. The RCS became very high with increase in curing age. This could be as a result of the adverse effect of acid on the concrete cubes which became more noticeable. The consequence is that, the durability of the concrete is reduced and this may even become more evident for longer curing age beyond 28 days. The increase in RCS with curing age could be attributed to the fact that, as curing age increases, the concentration of the acid also increased because of the evaporation of the curing water thus making the curing media more acidic (Reddy et al. 2012; Attah et al. 2018).

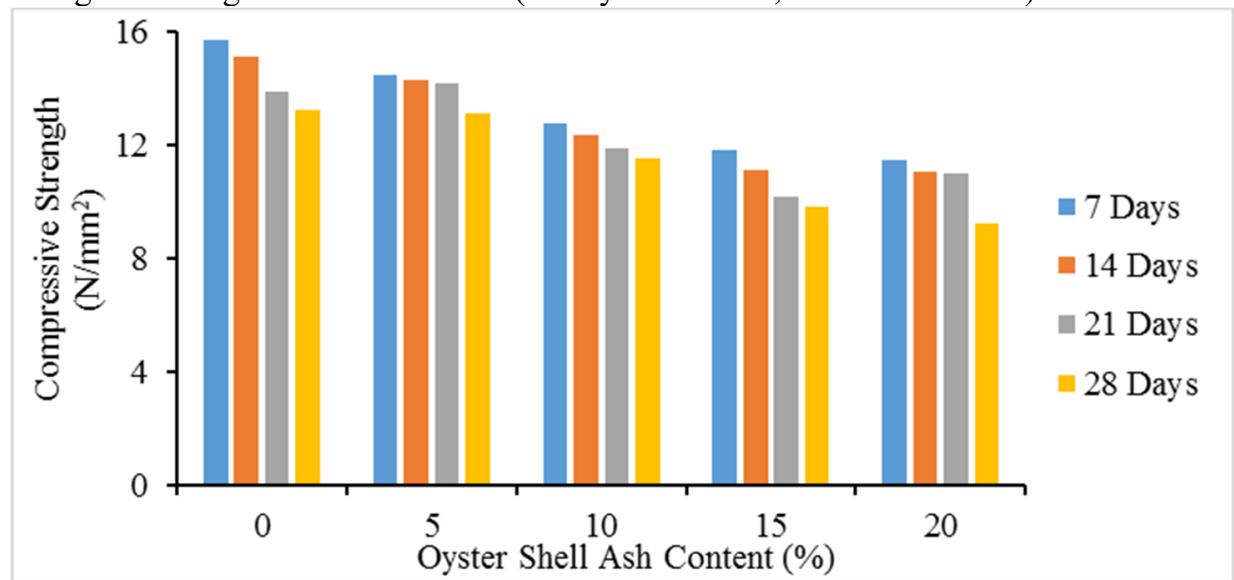

Figure 4. The Variation of compressive strength of blended cement -OSA concrete cubes with OSA replacement cured in $5 \% \mathrm{H}_{2} \mathrm{SO}_{4}$

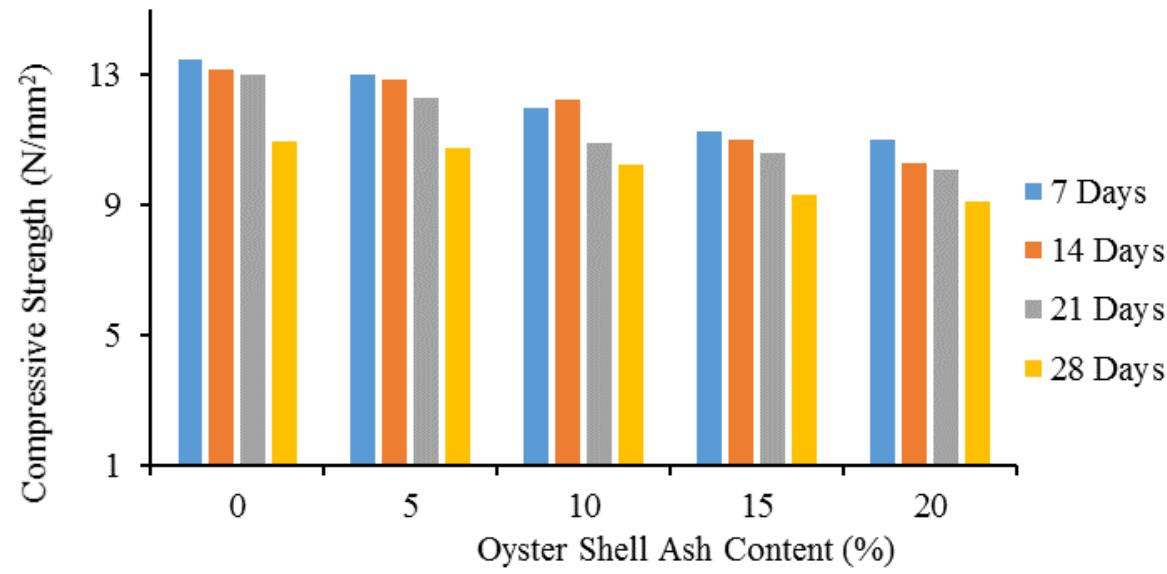

Figure 5: The Variation of compressive strength of blended cement -OSA concrete cubes with OSA replacement cured in $7.5 \% \mathrm{H}_{2} \mathrm{SO}_{4}$ 


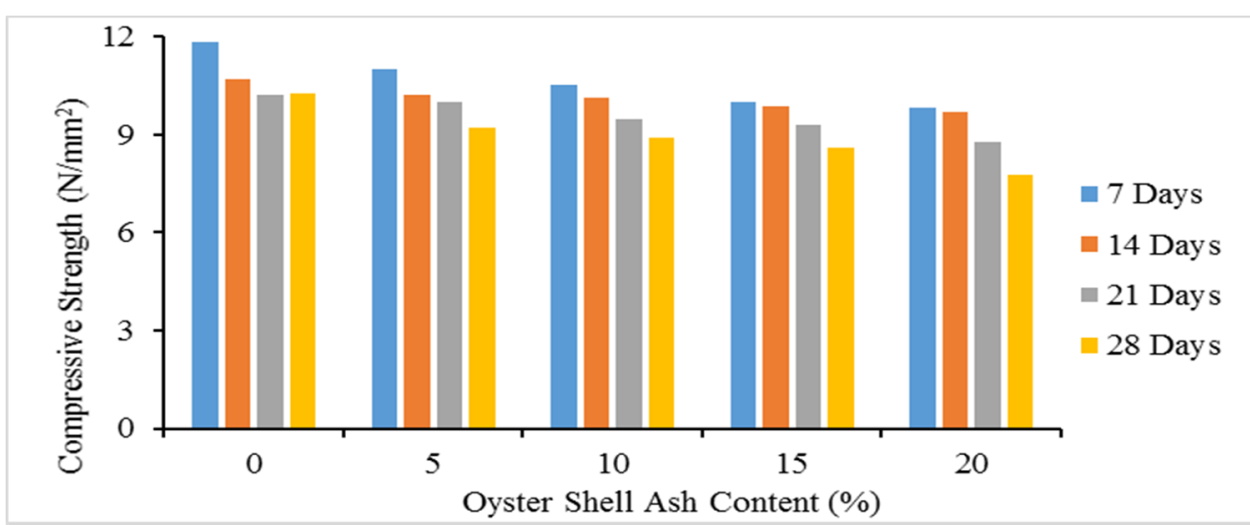

Figure 6. The Variation of compressive strength of blended cement - OSA concrete cubes with OSA replacement cured in $10 \% \mathrm{H}_{2} \mathrm{SO}_{4}$

Table 5. Compressive strength and reduction in compressive strength of cubes cured in potable water and sulphuric acid media $(5,7.5$ and $10 \%)$

\begin{tabular}{|c|c|c|c|c|c|c|c|c|}
\hline $\begin{array}{c}\text { Curing } \\
\text { age } \\
\text { (days) }\end{array}$ & $\begin{array}{c}\text { OSA } \\
\text { content } \\
(\%)\end{array}$ & $\begin{array}{l}\text { Cured in } \\
\text { potable } \\
\text { water } \\
\left(\mathrm{N} / \mathrm{mm}^{2}\right)\end{array}$ & $\begin{array}{c}\text { Cured in } \\
5.0 \% \\
\mathrm{H}_{2} \mathrm{SO}_{4} \\
\left(\mathrm{~N} / \mathrm{mm}^{2}\right)\end{array}$ & $\begin{array}{c}\text { Cured in } \\
7.5 \% \\
\mathrm{H}_{2} \mathrm{SO}_{4} \\
\left(\mathrm{~N} / \mathrm{mm}^{2}\right)\end{array}$ & $\begin{array}{c}\text { Cured in } \\
10 \% \\
\mathrm{H}_{2} \mathrm{SO}_{4} \\
\left(\mathrm{~N} / \mathrm{mm}^{2}\right)\end{array}$ & $\begin{array}{c}\mathrm{RCS} \\
5.0 \% \\
\mathrm{H}_{2} \mathrm{SO}_{4} \\
(\%)\end{array}$ & $\begin{array}{c}\mathrm{RCS} \\
7.5 \% \\
\mathrm{H}_{2} \mathrm{SO}_{4} \\
(\%)\end{array}$ & $\begin{array}{c}\mathrm{RCS} \\
10 \% \\
\mathrm{H}_{2} \mathrm{SO}_{4} \\
(\%)\end{array}$ \\
\hline \multirow[t]{5}{*}{7} & 0 & 20.98 & 15.69 & 13.48 & 11.83 & 25.21 & 35.75 & 43.61 \\
\hline & 5 & 19.16 & 14.46 & 13.01 & 10.99 & 24.53 & 32.10 & 42.64 \\
\hline & 10 & 17.86 & 12.77 & 11.98 & 10.51 & 28.50 & 32.92 & 41.15 \\
\hline & 15 & 16.26 & 11.80 & 11.25 & 10.02 & 27.43 & 30.81 & 38.8 \\
\hline & 20 & 15.96 & 11.47 & 11.02 & 9.81 & 28.13 & 30.95 & 38.53 \\
\hline \multirow[t]{5}{*}{14} & 0 & 27.50 & 15.12 & 13.19 & 10.69 & 45.02 & 52.04 & 61.13 \\
\hline & 5 & 21.22 & 14.28 & 12.87 & 10.22 & 32.70 & 39.35 & 51.84 \\
\hline & 10 & 20.67 & 12.34 & 12.24 & 10.12 & 40.30 & 40.78 & 51.04 \\
\hline & 15 & 19.55 & 11.10 & 11.02 & 9.87 & 43.22 & 43.63 & 49.51 \\
\hline & 20 & 19.79 & 11.05 & 10.28 & 9.71 & 44.16 & 48.05 & 50.93 \\
\hline \multirow[t]{5}{*}{21} & 0 & 29.12 & 13.87 & 12.99 & 10.32 & 52.37 & 55.39 & 64.56 \\
\hline & 5 & 26.55 & 14.16 & 12.28 & 9.99 & 46.67 & 53.75 & 62.37 \\
\hline & 10 & 26.11 & 11.88 & 10.88 & 9.48 & 54.50 & 58.33 & 63.69 \\
\hline & 15 & 25.31 & 10.20 & 10.58 & 9.29 & 59.70 & 58.20 & 63.30 \\
\hline & 20 & 23.58 & 11.01 & 10.09 & 8.77 & 53.31 & 57.21 & 62.81 \\
\hline \multirow[t]{5}{*}{28} & 0 & 32.89 & 13.26 & 10.95 & 10.25 & 59.68 & 66.71 & 68.84 \\
\hline & 5 & 28.14 & 13.13 & 10.75 & 9.22 & 53.34 & 61.80 & 67.24 \\
\hline & 10 & 27.38 & 11.53 & 10.22 & 8.91 & 57.89 & 62.67 & 67.46 \\
\hline & 15 & 26.22 & 9.83 & 9.33 & 8.59 & 62.51 & 64.42 & 67.24 \\
\hline & 20 & 25.28 & 9.23 & 8.30 & 7.79 & 63.49 & 67.17 & 69.19 \\
\hline
\end{tabular}

RCS $=$ Reduction in compressive strength

\subsection{Statistical Analysis}

\subsubsection{Analysis of variance}

The use of analysis of variance to establish the significant effect of replacing cement with pozzolanic admixture in concrete production had been reported by (Etim et al. 2017; Attah et al. 2018). Analysis of variance (two way) on the compressive strength was established to determine the possible effect of the source of variation. The various sources of variation considered are (1) OSA content and concentration of curing media for compressive strength of each curing age (2) OSA content and curing age for compressive strength attained from each concentration of curing media and (3) curing age and concentration of curing media for compressive strength established from each OSA percentage replacement. Summary of these result are shown in Table 6 - 8. The results were statistically significant for variations of OSA and acid concentration as well as OSA content and curing age. Similarly, for the case of variation of curing age and concentration of curing media, the concentration of curing media was statistically significant while curing age was not statistically significant. It can be observed that the significant effect which was considered at $95 \%$ confidence level was obtained when $\mathrm{F}_{\mathrm{CAL}}$ values were far greater than the $\mathrm{F}_{\text {CRIT }}$ values and p-values less 0.05 . 
Table 6. Two-way analysis of variance result for compressive strength of OSA/cement concrete at varying curing ages.

\begin{tabular}{|c|c|c|c|c|c|c|}
\hline Compressive strength & Source of variation & DOF & $\mathrm{F}_{\mathrm{CAL}}$ & P-value & $\mathrm{F}_{\mathrm{CRIT}}$ & Remark \\
\hline \multirow{2}{*}{7 days } & OSA content & 4 & 21.94 & $1.9 \mathrm{E}-05$ & 3.259 & $\mathrm{~F}_{\mathrm{CAL}}>\mathrm{F}_{\mathrm{CRIT}} \mathrm{SS}$ \\
\cline { 2 - 7 } & Acid conc. & 3 & 136.08 & $1.57 \mathrm{E}-09$ & 3.490 & $\mathrm{~F}_{\mathrm{CAL}}>\mathrm{F}_{\mathrm{CRIT}} \mathrm{SS}$ \\
\hline \multirow{3}{*}{14 days } & OSA content & 4 & 5.29 & 0.01084 & 3.259 & $\mathrm{~F}_{\mathrm{CAL}}>\mathrm{F}_{\mathrm{CRIT}} \mathrm{SS}$ \\
\cline { 2 - 7 } & Acid conc. & 3 & 70.19 & $7.03 \mathrm{E}-08$ & 3.490 & $\mathrm{~F}_{\mathrm{CAL}}>\mathrm{F}_{\mathrm{CRIT}} \mathrm{SS}$ \\
\hline \multirow{2}{*}{21 days } & OSA content & 4 & 11.15 & 0.000519 & 3.259 & $\mathrm{~F}_{\mathrm{CAL}}>\mathrm{F}_{\mathrm{CRIT}} \mathrm{SS}$ \\
\cline { 2 - 7 } & Acid conc. & 3 & 458.57 & $1.22 \mathrm{E}-12$ & 3.490 & $\mathrm{~F}_{\mathrm{CAL}}>\mathrm{F}_{\mathrm{CRIT}} \mathrm{SS}$ \\
\hline \multirow{2}{*}{28 days } & OSA content & 4 & 8.77 & 0.001498 & 3.259 & $\mathrm{~F}_{\mathrm{CAL}}>\mathrm{F}_{\mathrm{CRIT}} \mathrm{SS}$ \\
\cline { 2 - 7 } & Acid conc. & 3 & 337.42 & $7.75 \mathrm{E}-12$ & 3.490 & $\mathrm{~F}_{\mathrm{CAL}}>\mathrm{F}_{\mathrm{CRIT}} \mathrm{SS}$ \\
\hline
\end{tabular}

Table 7. Two-way analysis of variance result for compressive strength of OSA/cement concrete at varying percentage concentration of curing media

\begin{tabular}{|c|c|c|c|c|c|c|}
\hline Compressive strength & Source of variation & DOF & $\mathrm{F}_{\text {CAL }}$ & P-value & $\mathrm{F}_{\text {CRIT }}$ & Remark \\
\hline \multirow{2}{*}{$0 \% \mathrm{H}_{2} \mathrm{SO}_{4}$} & OSA content & 4 & 32.59 & $2.33 \mathrm{E}-06$ & 3.259 & $\mathrm{~F}_{\text {CAL }}>\mathrm{F}_{\text {CRIT }} \mathrm{SS}$ \\
\cline { 2 - 7 } & Curing age & 3 & 127.10 & $2.34 \mathrm{E}-09$ & 3.490 & $\mathrm{~F}_{\mathrm{CAL}}>\mathrm{F}_{\mathrm{CRIT}} \mathrm{SS}$ \\
\hline \multirow{2}{*}{$5 \% \mathrm{H}_{2} \mathrm{SO}_{4}$} & OSA content & 4 & 94.823 & $5.67 \mathrm{E}-09$ & 3.259 & $\mathrm{~F}_{\mathrm{CAL}}>\mathrm{F}_{\mathrm{CRIT}} \mathrm{SS}$ \\
\cline { 2 - 7 } & Curing age & 3 & 23.426 & $2.64 \mathrm{E}-05$ & 3.490 & $\mathrm{~F}_{\mathrm{CAL}}>\mathrm{F}_{\mathrm{CRIT}} \mathrm{SS}$ \\
\hline \multirow{2}{*}{$7.5 \% \mathrm{H}_{2} \mathrm{SO}_{4}$} & OSA content & 4 & 68.549 & $3.67 \mathrm{E}-08$ & 3.259 & $\mathrm{~F}_{\mathrm{CAL}}>\mathrm{F}_{\mathrm{CRIT}} \mathrm{SS}$ \\
\cline { 2 - 7 } & Curing age & 3 & 67.300 & $8.92 \mathrm{E}-08$ & 3.490 & $\mathrm{~F}_{\mathrm{CAL}}>\mathrm{F}_{\mathrm{CRIT}} \mathrm{SS}$ \\
\hline \multirow{2}{*}{$10 \% \mathrm{H}_{2} \mathrm{SO}_{4}$} & OSA content & 4 & 26.688 & $6.81 \mathrm{E}-06$ & 3.259 & $\mathrm{~F}_{\mathrm{CAL}}>\mathrm{F}_{\mathrm{CRIT}} \mathrm{SS}$ \\
\cline { 2 - 7 } & Curing age & 3 & 39.250 & $1.76 \mathrm{E}-06$ & 3.490 & $\mathrm{~F}_{\mathrm{CAL}}>\mathrm{F}_{\mathrm{CRIT}} \mathrm{SS}$ \\
\hline
\end{tabular}

Table 8. Two-way analysis of variance result for compressive strength of OSA/cement concrete at varying OSA replacement.

\begin{tabular}{|c|c|c|c|c|c|c|}
\hline Compressive strength & Source of variation & DOF & $\mathrm{F}_{\mathrm{CAL}}$ & P-value & $\mathrm{F}_{\mathrm{CRIT}}$ & Remark \\
\hline \multirow{2}{*}{$0 \%$ OSA } & Curing age & 3 & 0.165 & 0.9170 & 3.863 & $\mathrm{~F}_{\mathrm{CAL}}<\mathrm{F}_{\mathrm{CRIT}} \mathrm{NS}$ \\
\cline { 2 - 7 } & Conc. & 3 & 26.602 & $8.32 \mathrm{E}-05$ & 3.863 & $\mathrm{~F}_{\mathrm{CAL}}>\mathrm{F}_{\mathrm{CRIT}} \mathrm{SS}$ \\
\hline \multirow{2}{*}{$5 \%$ OSA } & Curing age & 3 & 0.242 & 0.8652 & 3.863 & $\mathrm{~F}_{\mathrm{CAL}}<\mathrm{F}_{\mathrm{CRIT}} \mathrm{NS}$ \\
\cline { 2 - 7 } & Conc. & 3 & 23.485 & $1.37 \mathrm{E}-04$ & 3.863 & $\mathrm{~F}_{\mathrm{CAL}}>\mathrm{F}_{\mathrm{CRIT}} \mathrm{SS}$ \\
\hline \multirow{2}{*}{$10 \%$ OSA } & Curing age & 3 & 0.223 & 0.8782 & 3.863 & $\mathrm{~F}_{\mathrm{CAL}}<\mathrm{F}_{\mathrm{CRIT}} \mathrm{NS}$ \\
\cline { 2 - 7 } & Conc. & 3 & 21.510 & $1.93 \mathrm{E}-04$ & 3.863 & $\mathrm{~F}_{\mathrm{CAL}}>\mathrm{F}_{\mathrm{CRIT}} \mathrm{SS}$ \\
\hline \multirow{2}{*}{$15 \%$ OSA } & Curing age & 3 & 0.236 & 0.8692 & 3.863 & $\mathrm{~F}_{\mathrm{CAL}}<\mathrm{F}_{\mathrm{CRIT}} \mathrm{NS}$ \\
\hline & Conc. & 3 & 17.941 & $3.87 \mathrm{E}-04$ & 3.863 & $\mathrm{~F}_{\mathrm{CAL}}>\mathrm{F}_{\mathrm{CRIT}} \mathrm{SS}$ \\
\hline \multirow{2}{*}{$20 \%$ OSA } & Curing age & 3 & 0.175 & 0.9108 & 3.683 & $\mathrm{~F}_{\mathrm{CAL}}<\mathrm{F}_{\mathrm{CRIT}} \mathrm{NS}$ \\
\cline { 2 - 7 } & Conc. & 3 & 20.012 & $2.55 \mathrm{E}-04$ & 3.863 & $\mathrm{~F}_{\mathrm{CAL}}>\mathrm{F}_{\mathrm{CRIT}} \mathrm{SS}$ \\
\hline
\end{tabular}

Conc. $=$ Concentration, DOF $=$ Degree of freedom, $\mathrm{SS}=$ Statistically significant, NS $=$ Not significant.

4.6.2 Regression analysis

The formulation of conceptual model based on dependent and independent variables had been used in various field of civil of engineering (Bassey et al. 2017; Ogork and Ibrahim, 2017). Regression analysis was done for the various compressive test result obtained from the various curing media. The compressive strength was considered dependent variable while oyster shell ash content and curing age were taken as independent variables. The representative regression equations generated for compressive strength of OSA-PLC concrete ranging from the control media $\left(0 \% \mathrm{H}_{2} \mathrm{SO}_{4}\right)$ to the various concentration of curing media are given in equations $2-5$.

$$
\begin{aligned}
& F C_{\left(0 \% \mathrm{H}_{2} \mathrm{SO}_{4}\right)}=17.9-0.2970 S A+0.489 C A \\
& F C_{\left(5 \% \mathrm{H}_{2} \mathrm{SO}_{4}\right)}=16.1-0.2170 S A+0.0869 C A \\
& F C_{\left(7.5 \% \mathrm{H}_{2} \mathrm{SO}_{4}\right)}=14.6-0.1430 S A+0.104 C A \\
& F C_{\left(10 \% \mathrm{H}_{2} \mathrm{SO}_{4}\right)}=12.1-0.0833 O S A-0.0799 \mathrm{CA}
\end{aligned}
$$

where; $F C$ is the concrete compressive strength at $0,5,7.5$ and $10 \%$ concentration of $\mathrm{H}_{2} \mathrm{SO}_{4}$ curing media, OSA is the oyster shell ash at $0,5,10,15$ and $20 \%$ and $\mathrm{CA}$ is the curing age of samples at 7,14, 21 and 28 days. At $5 \%$ level of significance, from the regression analysis, $\mathrm{P}$-value $=0.000$ for both OSA content and age of curing of concrete, respectively and shows that both variables are significant $(\mathrm{P}<0.05)$ signifying that the variation in the concrete compressive strength in $0,5,7.5$ and $10 \% \mathrm{H}_{2} \mathrm{SO}_{4}$ curing media is caused by OSA content and age of curing. The coefficients of determination, $\left(\mathrm{R}^{2}\right)$ for the different curing media are shown in Table 9. The $\mathrm{R}^{2}$ values indicate that the variation of concrete strengths is significantly dependent on the variations of OSA content and age of curing. 
Table 9. Coefficients of determination, $\left(\mathrm{R}^{2}\right)$ for the different curing media

\begin{tabular}{|l|c|c|c|c|}
\hline $\begin{array}{l}\text { Curing } \\
\text { media }\end{array}$ & $0 \% \mathrm{H}_{2} \mathrm{SO}_{4}$ & $5 \% \mathrm{H}_{2} \mathrm{SO}_{4}$ & $7.5 \% \mathrm{H}_{2} \mathrm{SO}_{4}$ & $10 \% \mathrm{H}_{2} \mathrm{SO}_{4}$ \\
\hline $\mathrm{R}^{2}$ value (\%) & 91.80 & 90.20 & 90.70 & 93.10 \\
\hline
\end{tabular}

However, further statistical tests such as the residual and normality plots were used to check how well the models fit the data used. The data used were drawn from the compressive strength obtained for concrete cured in $0,5,7.5$ and $10 \% \mathrm{H}_{2} \mathrm{SO}_{4}$. The residual and normality plots are shown in Figs. 7 and 8; 9 and 10; 11 and 12 ; 13 .and 14. It was observed that there were few large residuals and limited apparent outlier. The findings of the current study are consistent with those of (Ogork and Ibrahim, 2017) who used calcium carbide waste as additive in concrete to establish a model. The results further confirm that the models are adequate for design prediction similar to the study of Razak and Wong (2004) as well as Elinwa and Abdulkadir (2011).

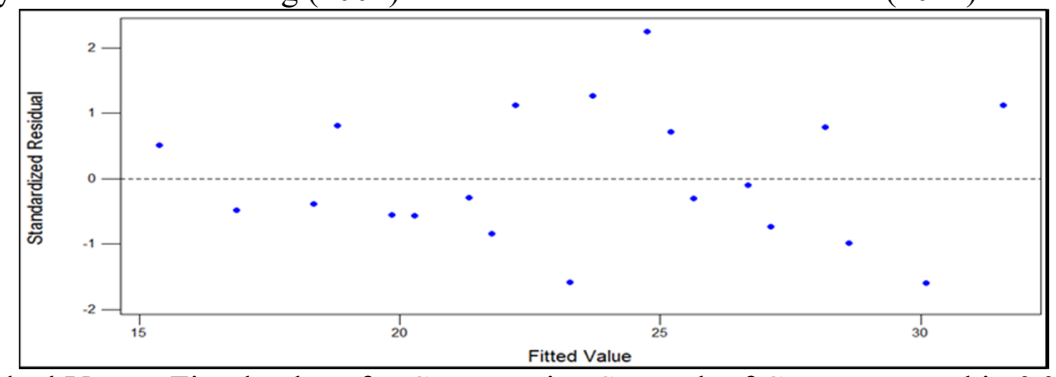

Figure 7. Residual Versus Fitted values for Compressive Strength of Concrete cured in $0 \% \mathrm{H}_{2} \mathrm{SO}_{4}$ media

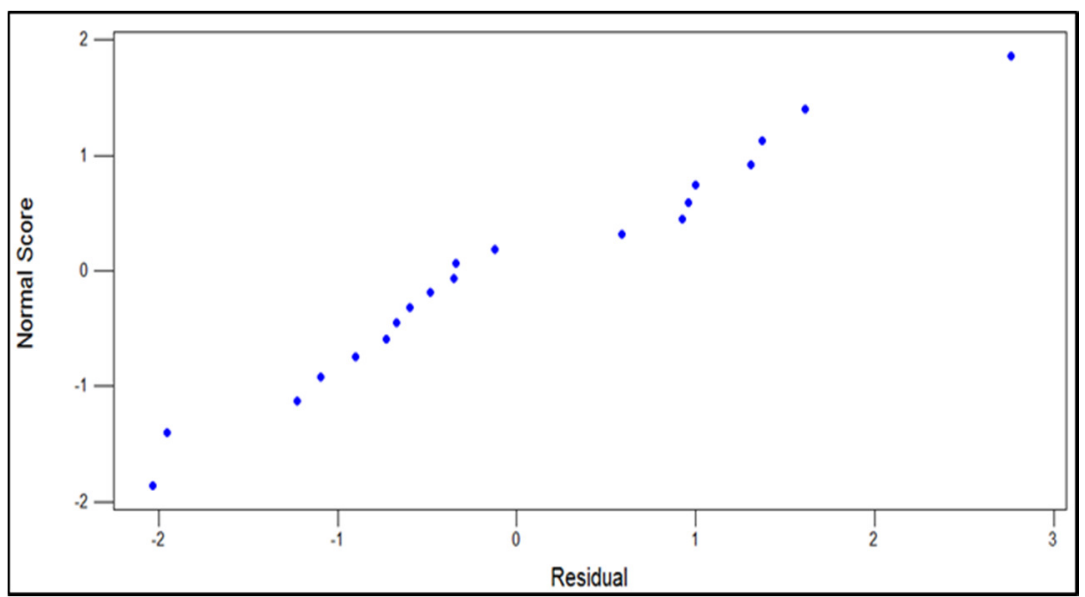

Figure 8. Normal Probability of Residuals for Compressive Strength of Concrete cured in $0 \% \mathrm{H}_{2} \mathrm{SO}_{4}$ media

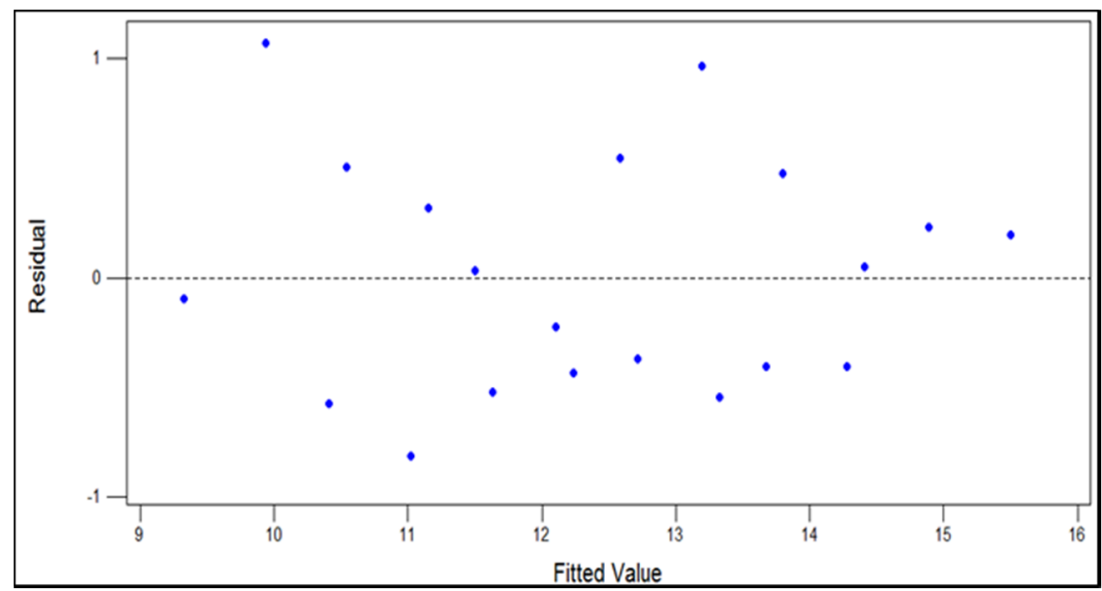

Figure 9. Residual Versus Fitted values for Compressive Strength of Concrete cured in $5 \% \mathrm{H}_{2} \mathrm{SO}_{4}$ media. 


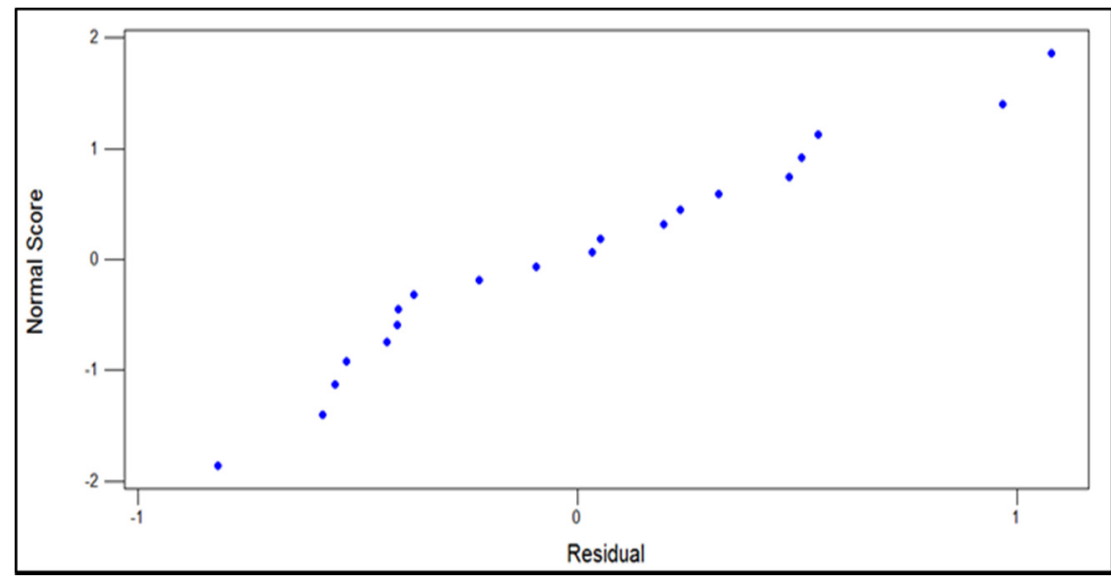

Figure 10. Normal Probability of Residuals for Compressive Strength of Concrete cured in $5 \% \mathrm{H}_{2} \mathrm{SO}_{4}$ media.

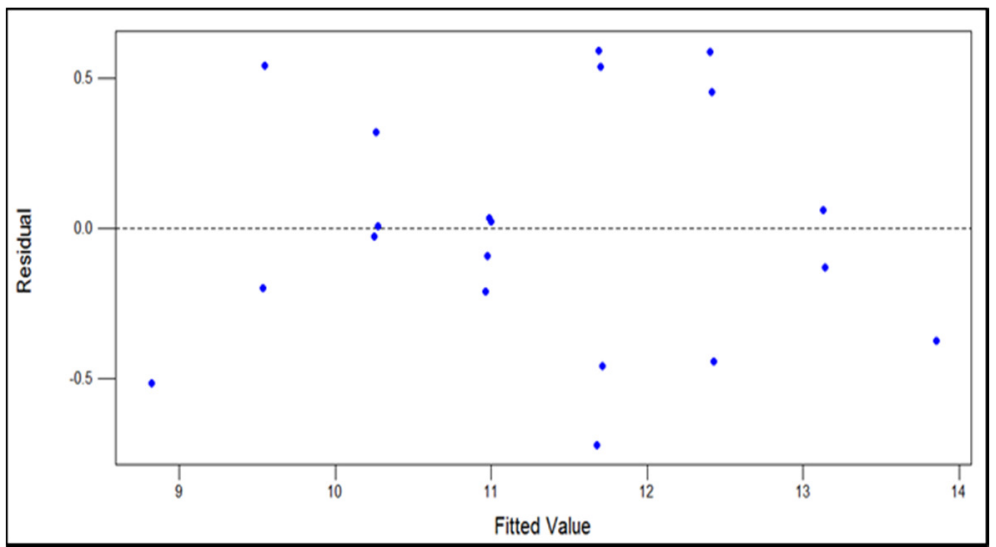

Figure 11. Residual Versus Fitted values for Compressive Strength of Concrete cured in $7.5 \% \mathrm{H}_{2} \mathrm{SO}_{4}$ media.

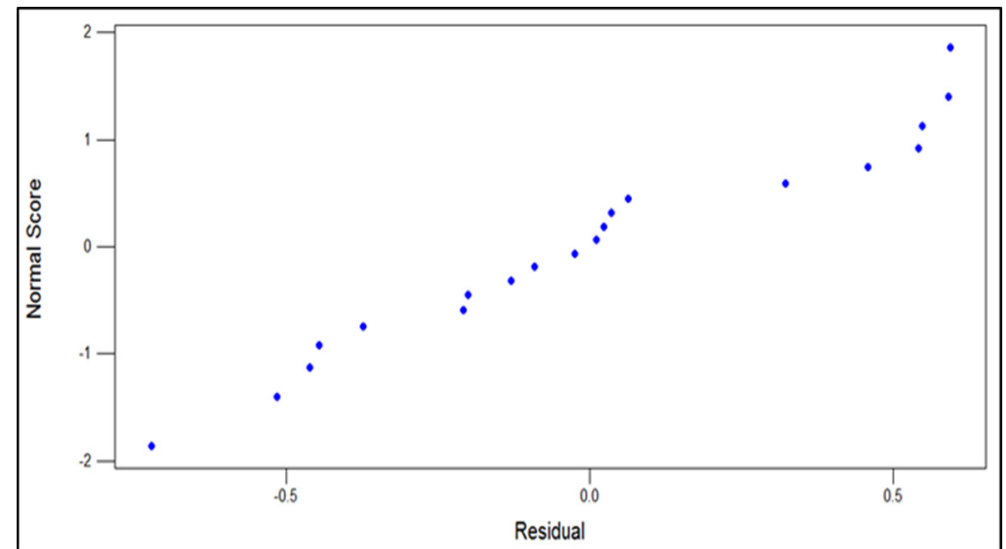

Figure 12. Normal Probability of Residuals for Compressive Strength of Concrete cured in $7.5 \% \mathrm{H}_{2} \mathrm{SO}_{4}$ media 


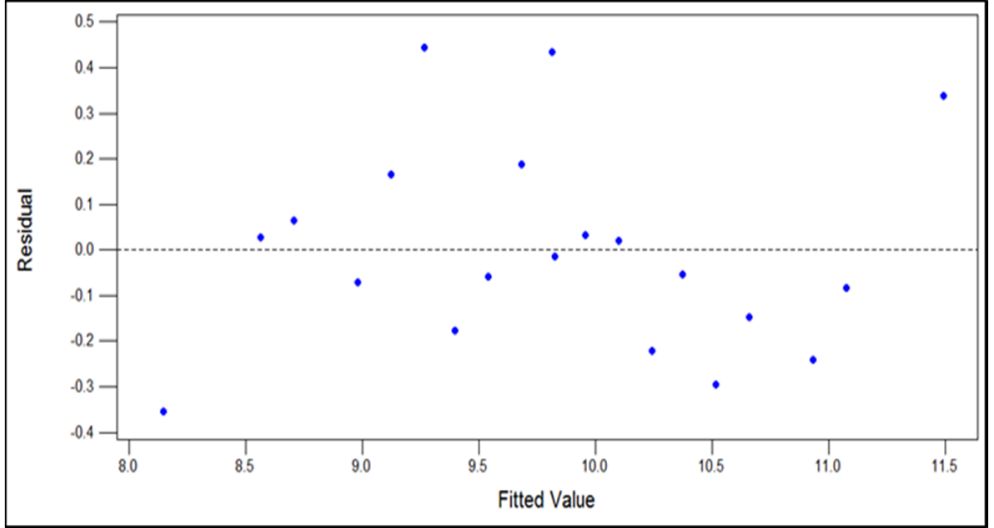

Figure 13: Residual Versus Fitted values for Compressive Strength of Concrete cured in $10 \% \mathrm{H}_{2} \mathrm{SO}_{4}$ media.

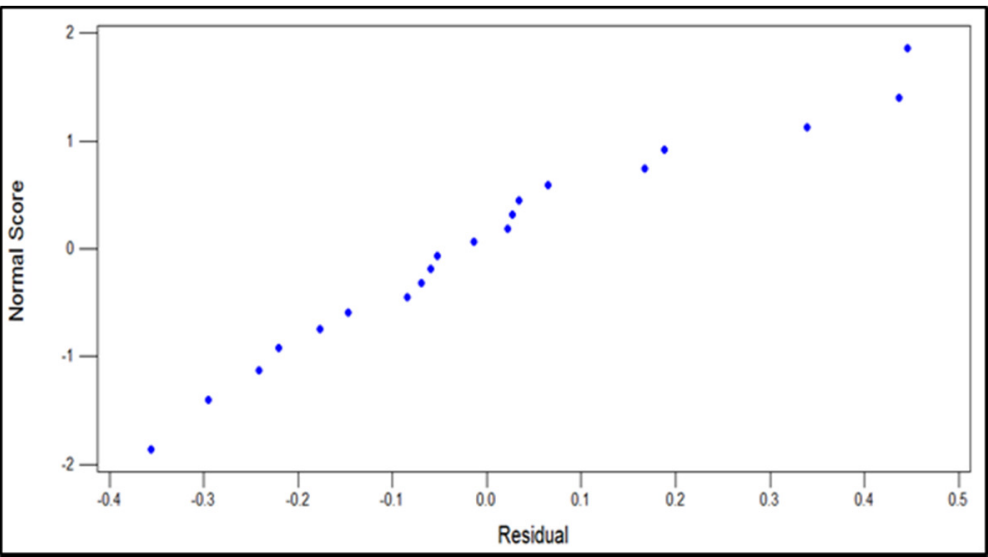

Figure 14. Normal Probability of Residuals for Compressive Strength of Concrete cured in $10 \% \mathrm{H}_{2} \mathrm{SO}_{4}$

\section{Conclusion}

The following findings are based on the laboratory results reported in this paper. The specific conclusions that can be outline from this study are as follows:

- Sulphuric acid and curing ages had negative effects on the compressive strength. Specimens cured in $0 \%$ $\mathrm{H}_{2} \mathrm{SO}_{4}$ yielded higher compressive strength compared to the concrete cubes cured in sulphuric acid media.

- The anova test showed that the sulphuric acid concentrations, OSA contents and curing age have significant effect on the compressive strength of concrete.

- The usage of OSA as supplementary cementitious material (SCM) in concrete did not mitigate the chemical effect of sulphuric acid on concrete cubes.

- Regression models for concrete cured in $0,5,7.5$ and $10 \%$ concentration of $\mathrm{H}_{2} \mathrm{SO}_{4}$ with $\mathrm{R}^{2}$ values of $91.80,90.20,90.70$ and $93.10 \%$ respectively are adequate for the prediction of concrete strength.

\section{References}

Abinaya, S. \& Venkatesh, S.P. (2016), "An effect on oyster shell powder's mechanical properties in selfcompacting concrete”, Int. Journal of Innovative Research in Sci., Eng. and Tech. 5(6), 11785-11789.

Adesanya, D.A. \& Raheem, A.A. (2009), "A study of the workability and compressive strength characteristics of corn cob ash blended cement concrete", Construction and Build. Materials 23(1), 311-317.

ASTM (1998), "Standard test methods for particle size analysis of soil, D 422-63", ASTM International, West Conshohocken, PA.

ASTM (2008), "Specification for coal fly ash and raw or calcined natural pozzolanas for use as mineral admixtures in Ordinary Portland Cement Concrete. C 618", Annual book of ASTM standards, West Conshecken, U.S.A.

ASTM (2012), "Standard specification for mixing water used in the production hydraulic cement concrete. C1602-12", ASTM International, West Conshohocken, PA.

Attah, I.C., Etim, R.K. \& Ekpo, D.U. (2018), "Behaviour of periwinkle shell ash blended cement concrete in sulphuric environment", Nigerian Journal of Technology 37(2), 315 - 321.

Bapat, J.D. (2012), "Mineral admixtures in cement and concrete", $1^{\text {st }}$ Edition, CRC Press Taylor and Francis 
Group, USA.

Bassey, O.B., Attah, I.C., Ambrose, E.E. \& Etim, R.K. (2017), "Correlation between CBR values and index properties of soils: A case study of Ibiono, Oron and Onna in Akwa Ibom State", Resources and Environment 7(4), 94-102.

Bhikshma, V., Nitturkar, K. \& Venkatesham, Y. (2009), "Investigations on mechanical properties of high strength silica fume concrete", Asian Journal of Civil Engineering (Building and Housing) 10(3), 335-346.

British Standard Institution (1983), "Method for determination of compressive strength of concrete cubes, BS 1881 Part 116", British Standard Institution, London.

British Standard Institution (1983), "Methods for determination of density of hardened concrete cubes, BS 1881114", British Standard Institution, London.

British Standard Institution (1992), "Grading limits for fine aggregates, BS 882 Part 2", British Standard Institution, London.

British Standard Institution (2002), “Aggregates for concrete. BS EN 12620,” British Standard Institution, London.

British Standard Institution (2009), "Methods for determination of compressive strength, BS EN 12390, Part 3", British Standard Institution, London.

British Standard Institution (2009), "Testing fresh concrete: Slump Test, BS EN 12350, Part 2", British Standards Institution, London.

British Standards Institution (1997), "Concrete code of practice, BSI 8110: Part 1”, British Standards Institution, London.

Elinwa, A.U. \& Abdulkadir, S. (2011), "Characterizing sawdust ash for use as an inhibitor for reinforcement corrosion", New Clues in Sciences 1, 1-10.

Etim, R.K., Attah, I.C. \& Bassey, O.B. (2017), “Assessment of periwinkle shell ash blended cement concrete in crude oil polluted environment", FUW Trends in Science and Technology Journal 2(2), 879 - 885.

Etuk, B.R., Etuk, I.F. \& Asuquo, L.O. (2012), "Feasibility of using sea shells ash as admixtures for concrete", Journal of Environmental Science and Engineering A 1: 121-127.

Liang, C. and Wang, H. (2013), "Feasibility of pulverized oyster shell as a cementing material", Advances in Materials Science and Engineering 2013, 1 - 7.

Mehta, P.K. \& Monteiro, P.J.M. (2006), “Concrete: microstructure, properties and materials”, $3{ }^{\text {rd }}$ Ed., New Delhi, McGraw-Hill publishing company Ltd.

Miyaji, Y. \& Okamura, T. (2000), "Geo-material properties of wasted oyster shell sand mixture and its application as material for sand compaction pile", In the Proceedings of Coastal Geotechnical Engineering in Practice, 675-680, Rotterdam, Netherlands.

Nabil, M.A. (2016), "Durability of metakaolin concrete to sulphate attack", Cement and Concrete Research 36, $1727-1734$.

Neville, A.M. (2000), "Properties of concrete", $5^{\text {th }}$ Edition. Pitman Publishing Ltd. London.

Neville, A.M. (2008), "Properties of concrete", $4^{\text {th }}$ Edition, Pearson Prentice Hall, Malaysia.

Neville, A.M. \& J.J. Brooks (1997), “Concrete technology”, $2^{\text {nd }}$ Edition. Longman Publishing Ltd. Singapore.

Nigerian Industrial Standard (2003), "Composition, specifications and conformity criteria for common cements, NIS 444-1", Standard Organization of Nigeria.

Ogork, E.N. \& Ibrahim, T.S. (2017), "Properties of cement paste and concrete containing calcium carbide waste as additive", Nigerian Journal of Technology 36(1), 26-31.

Olivia, M., Mifshella, A.A. \& Darmayantia, A. (2015), "Mechanical properties of seashell concrete", The $5^{\text {th }}$ International Conference of Euro Asia Civil Engineering Forum (EACEF-5). Procedia Engineering, 125, 760-764.

Olonade, K.A., Olajumoke, A.M., Omotosho, A.O. \& Oyekunle, F.A. (2014), "Effects of sulphuric acid on the compressive strength of blended cement / cassava peel ash concrete". Construction Materials and Structures, 764-771. Doi: 10.3233/978-1-61499-466-4-764.

Olusola, K.O. \& Umoh, A.A. (2012), "Strength characteristics of periwinkle shell ash blended with cement concrete". International Journal of Architecture, Engineering and Construction, 1(4), 213-220.

Ookame, Y., Hatano, Y. \& Kawai, K. (2013) "Study on long term concrete deterioration due to sulphuric acid". Proceedings of the Third International Conference on Sustainable Construction Materials and Technologies, Kyoto Research Park, Kyoto, Japan, August $18^{\text {th }}-21^{\text {st }}$.

Oyedepo, O.J. (2017), "Laboratory investigation of the use of crushed oyster shell and crushed palm kernel shell in bituminous mix design". Malaysian Journal of Civil Engineering, 29(1), 15-27.

Page, C.L. \& Page, M.M. (2007), "Durability of concrete and cement composites", $1^{\text {st }}$ Edition, Woodhead Publishing Ltd, Cambridge, England.

Razak, H.A. and Wong, H.S. (2004), "Strength estimation model for high-strength concrete incorporating metakaolin and silica fume", Cement and Concrete Research, 35, 688-695. 
Reddy, B.M., Rao, H.S. \& George, M.P. (2012), "Effect of hydrochloric acid on blended cement (Fly Ash Based) and silica fume blended cements and their concretes", International Journal of Science and Technology, 1(9), 467-480.

Sahmaran, M., Kasap, O., Duru, K. \& Yaman, I.O. (2007), "Effects of mix composition and water -cement ratio on the sulphate resistance of blended cements", Cement and Concrete Composites, 29(3), 159-167.

Sai-Prasad, P.V. \& Jha, K. (2006), "High performance concrete", Project work done for course No.624-Sr. Professional course (Bridges and General).

Salah, U.A. (2007), "Sulphate resistance of plain and blended cements exposed to magnesium sulphate solutions", Construction and Building Materials, 21, 1792-1802.

Sathawane, S.H., Vairagade, V.S. \& Kene, K.S. (2013), "Combine effect of rice husk ash and fly ash on concrete by $30 \%$ cement replacement", Procedia Engineering, 51, 35-44.

Shetty, M. S. (2005), "Concrete technology”, Theory and Practice: S. Chand and Company, New Delhi.

Shetty, M. S. (2009), "Concrete Technology", Theory and Practice. New Delhi: Rajendra Ravinda Printer.

Shetty, M.S. (2012), "Concrete Technology". Theory and Practice (6 $6^{\text {th }}$ revised Ed.) New Delhi: S. Chand.

Soeda, M., Yamato, T. \& Emoto, Y. (1991), "Influence of combined admixture on the chemical resistance of concrete", Cement Science and Concrete Technology, 45, 228-233.

Spangler, M.G. \& Handy, R.L. (1982), "Soil Engineering", $4^{\text {th }}$ Edition, Harper and Row Publishers Inc., New York.

Turkel, S., Felekoglu, B. \& Dulluc, S. (2007), "Influence of various acids on the physico-mechanical properties of pozzolanic cement mortars", Sadhana, 32(6), 683-691.

$\mathrm{Wu}$, T.H. (2000). "Study on the stabilization of various road bed soils using pulverized oyster shells", M.S. thesis, National Cheng Kung University, Taiwan.

Yoon, G.L., Kim, B.T., Kim, B. O. \& Han, S.H. (2003), “Chemical-mechanical characteristics of crushed oystershell", Waste Management, 23(9), 825 - 834.

Yuan, H., Dangla, P., Chatellier, P. \& Chaussadent, T. (2013), "Degradation modelling of concrete submitted to sulphuric acid attack", Cement and Concrete Research, 53, $267-277$.

Zhang, M.H. \& Mohan, M.V. (1996), "High performance concrete incorporating rice husk ash as a supplementary cementing material”, ACI Materials Journal, 93(6), 629-636.

Zhong, B.Y., Zhou, Q., Chan Y, C.F. \& Yu, Y. (2012), "Structure and property characterization of oyster shell cementing material", Chinese Journal of Structural Chemistry, 31(1),85-92.

Zivica, V. \& Bajza, A. (2001), “Acid attack on cement based materials - A review, part 1", Construction and Building Materials, 15(8), 331-340.

Zivica, V., Palou, M., Krizmaand, M. \& Bagel, L. (2012), “Acidic attack of cement based materials under the common action of high ambient temperature and pressure", Construction and Building Materials, 36, 623 629. 